\title{
The Socio-economic Factors Affecting Plant Home Gardens
}

\author{
Jawad Atef Al-Dala'een ${ }^{1}$ \\ ${ }^{1}$ Assistant Prof. of Agricultural Economics, Karak University College, Balqa Applied University, Jordan \\ Correspondence: Jawad Atef Al-Dala'een, Assistant Prof. of Agricultural Economics, Karak University College, \\ Balqa Applied University, Jordan.
}

Received: November 15, 2017

Accepted: December 18, 2017

Online Published: December 25, 2017

doi:10.5430/ijba.v9n1p28

URL: https://doi.org/10.5430/ijba.v9n1p28

\begin{abstract}
The objective of this research is to highlight the socio-economic characteristics of households that practice urban plant production through their household gardens. The questionnaire was a tool used to collect data. Stratified sample was which divided the population into six strata. The first five strata were depending on family income, while the sixth strata was depending on the households in suburban areas. The results showed that the distribution of gardens was affected by the family income, the free space inside household. Most of households showed that the production is used either for family consumption or used as entertainment tool inside household. The educational level affected the care for household gardens. In low income families, the low educational individual used to care for gardens, while the contrary was recorded for higher income layers. In the suburban areas, the care for garden was taken over by all family members.
\end{abstract}

Keywords: socio-economic, household gardens, plant production

\section{Introduction}

Family economic challenges increased as the inflation increases and the income is constant especially in developing countries. Moreover, the environmental challenges increased due to high production needs to meet the increase of population and degradation of natural sources (Gbedomon, R., et al. 2015). Home gardens considered one of the solutions either to save part of family food or to increase family income. Some authors consider family gardens as a tool to alleviate poverty and to avoid hunger (Fandohan et al. 2011).

In countries of low arable land areas, home gardens considered a tool to use the arable lands in urban and sub-urban areas. The plant production in these areas supported by household gardens. In some areas they interested in household garden production as part of household food and nutrition (Domene and Sauri, 2007; Mazzumdar and Mazzumdar, 2011). In some countries they consider the household production as part of the economic indicators, moreover, other countries consider that the percentage of household gardens as part of economic and political development of a country (Burn et al., 1989; Faber et al. 2002). In environmental aspects, household garden is considered as a tool to reserve biodiversity (Salako et al., 2014; Avohou et al., 2012; Abet et al., 2013).

Economically, the household garden is considered as one of the activities that contribute to family income as well as considered a home job for women and old men, who used to care and practice these activities (Igue, et al., 2000). This traditional behavior changed overtime. The socio-economic characteristics reflected through the new ages thought of farming as a tool of refreshment and environment reserve, also their attitude to change lifestyle (Coomes et al., 2004; Trinth, et al., 2003; Watson et al., 2002).

This research objected to investigate the distribution of household garden and the socio-economic characteristics of owners of these gardens in urban and sub-urban areas. Also, this research will investigate the nature of plant production and some inputs and outputs of this activity.

\section{Methodology}

Jordan is a country with small area and the percentage of arable land is very small of the total area. Under such conditions the care for household planting is one of the tools that will improve the use of arable land in one direction and improves family income or increase savings through the household production. The objective of this research is to investigate the socio-economic structure of household that have gardens in urban and sub-urban areas in Jordan knowing that more than $87.7 \%$ of the population are living in urban and suburban areas and the average income of 
the family is $3215 \$$.

To accomplish the objectives of this research, field survey was executed to investigate the distribution of urban agriculture. The survey included households in urban and suburban areas in large cities specially Amman; the capital of Jordan. The study population was divided into different strata as follow:

Layers classification

Layers 1: represents the people with low income

Layer 2: represents people with low to moderate income

Layer 3: represents people from moderate to high income

Layer 4: represents the people with high income

Layer 5: represents Wadi Al Ssir Area

Layer 6: represents Amman suburbs

Simple random sample selected in harmony with sample size from each strata. A questionnaire used as a tool for data collection. The questionnaire covered two parts. The first part was concerned with plant production, which the concern of this paper, while the other part covers the animal production, which discussed in another paper abstracted from the same survey. The questionnaire included different parts. The first part was concerned with farming inputs for plant and animal production, which a second part was concerned with the socio-economic characteristics of families. Also, another part of the questionnaire was concerned with environmental effect of urban agricultural activities which will be discussed in a separate paper, too.

\section{Results and Discussion}

The percentage of household gardens was associated with the location of household. The highest percentage of household gardens found in layer sixth which represents the suburbs areas of Amman governorate with percentage $45.2 \%$, while the lowest percentage of gardens associated with households found in layer 2 which represents the low to moderate households with percentage $7.7 \%$. The distribution of household gardens varied from layer to another, but still shows some pattern, which increases as the household income increases in the third and fourth layers. This indicates that another factor will determine the distribution of household gardens, which is the household income. The results revealed that the households believe that the household garden requires more expenses (Figure 1).

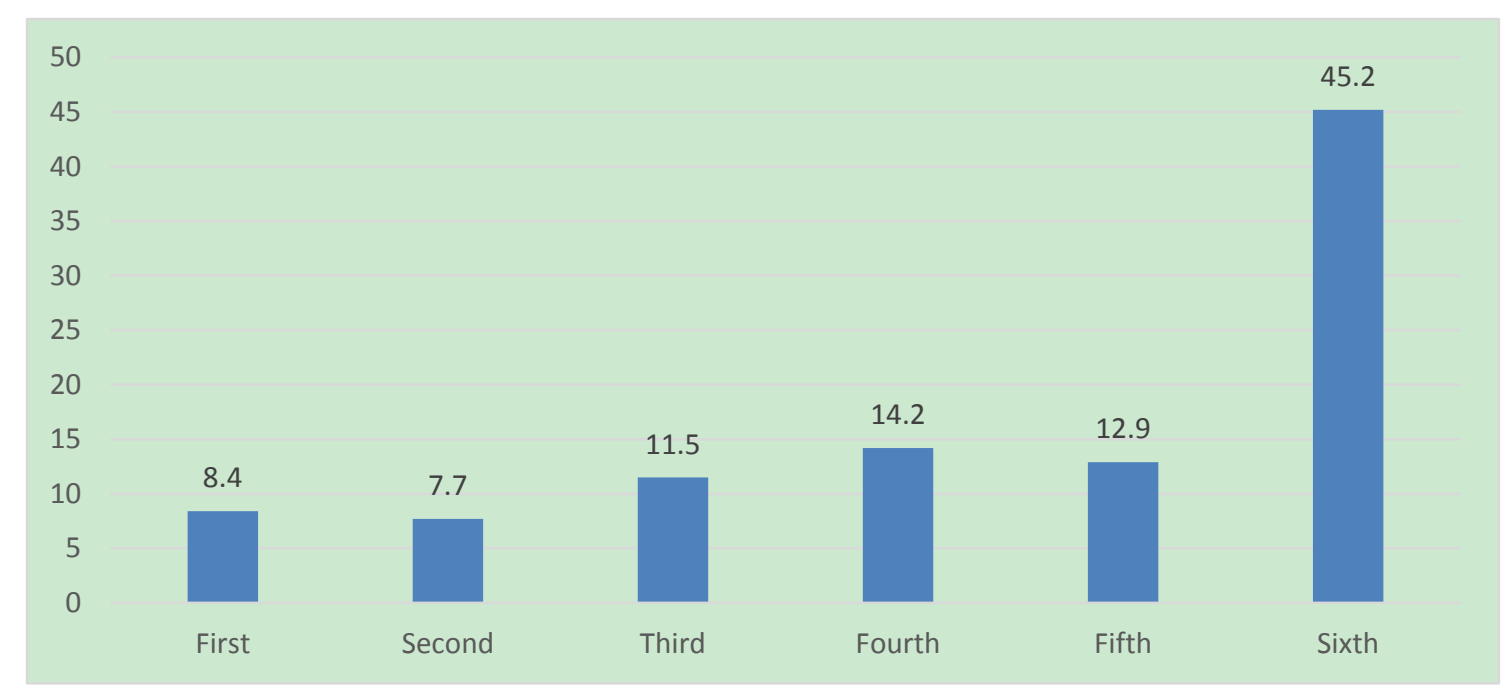

Figure 1. The percentage of household gardens distribution according to layer

The household gardens percentage varied according to the free space available in the household (Figure 2). In the first layer, the highest percentage of gardens were available in households with free space less than $20 \mathrm{~m}^{2}$. Also, the second layer ad third layers showed the same patterns. The patterns of gardens distribution according to free space change in the fourth, fifth and sixth layers. In fourth layer, the highest garden distribution was in households with 
free space ranges from 50-100 $\mathrm{m}^{2}$, while in the fifth layer the highest percentage of gardens found in households with $100-200 \mathrm{~m}^{2}$, and in the sixth layer the highest percentage of gardens distributed among households with free space more than $200 \mathrm{~m}^{2}$. The previous results explain that the distribution of gardens depend on two factors. The first factor is the household income and the second factor is the free space of household.

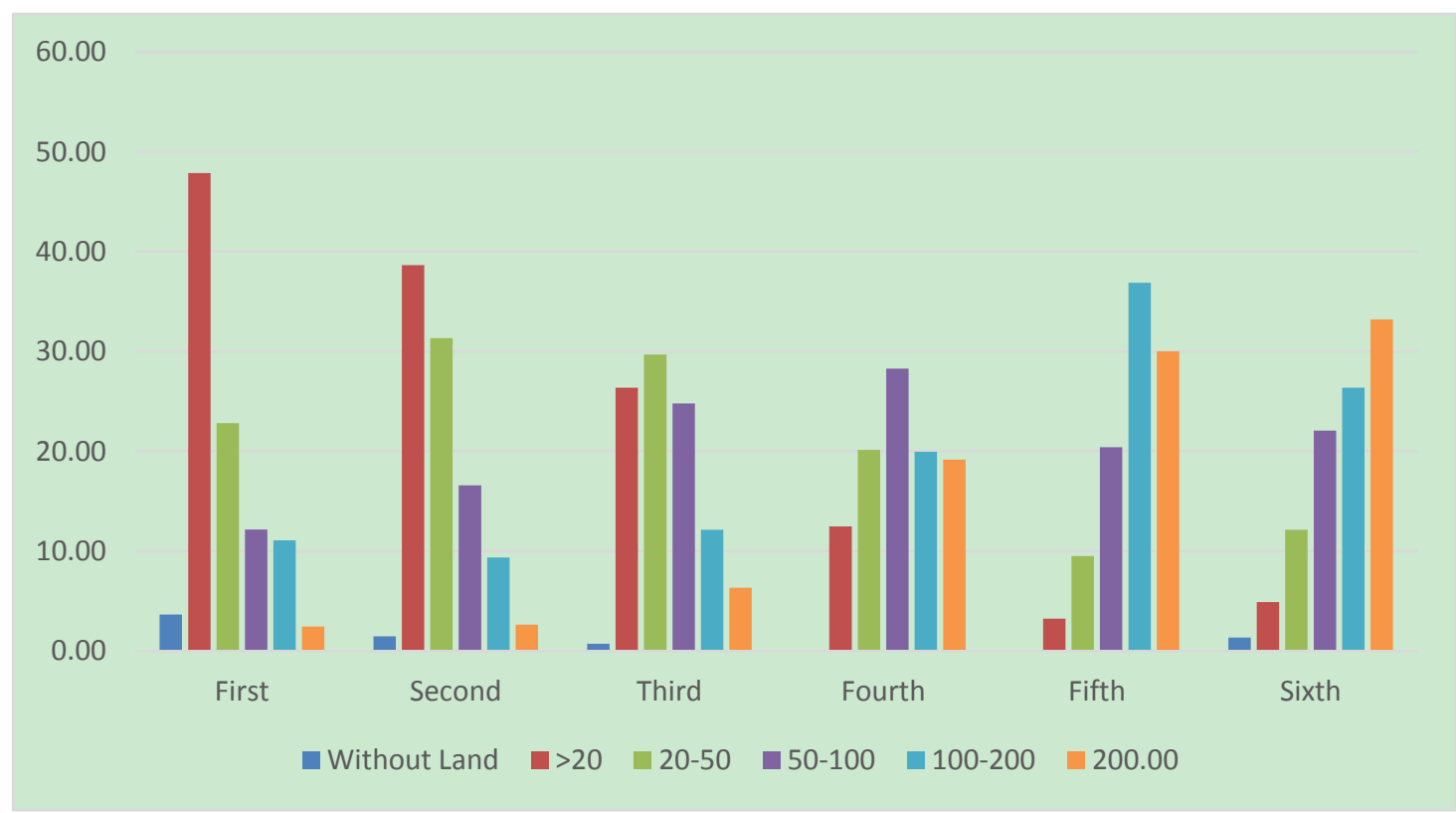

Figure 2. The percentage of distribution of gardens area over the different spaces

The most dominant crop pattern in household gardens is the bearing trees followed by trellis and climbers and the third rank was for shrubs and fences. The rest of crops planted was distributed among vegetables, ornamental plants and aromatic and medical plants. The distribution of type of plant depends on the effort required to care for the garden. Most of households believed that the trees is the least type of plants that requires care and follow up.

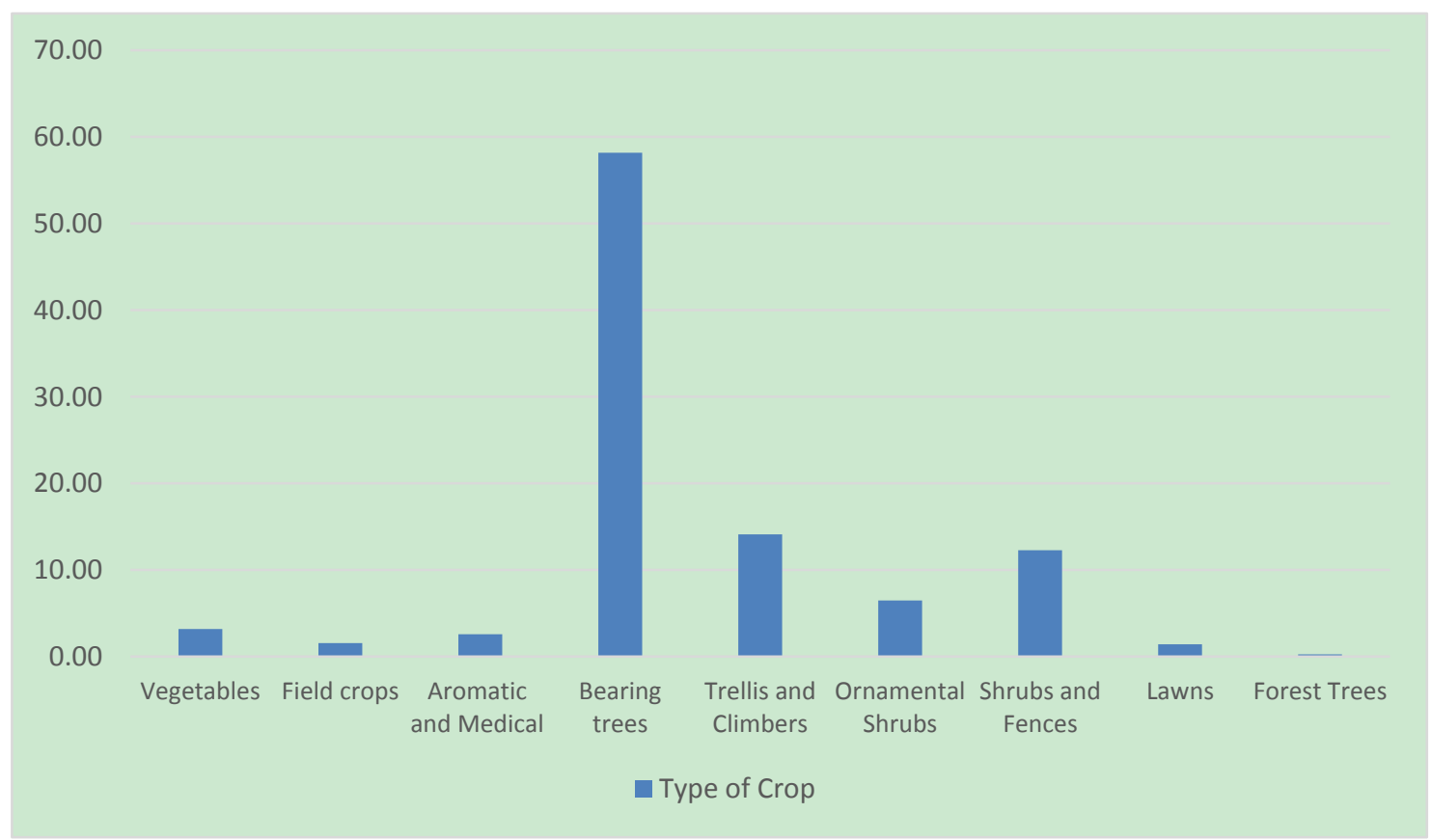

Figure 3. The distribution of type of crops planted in urban agriculture 
The highest percentage of vegetables were planted in gardens with areas $>200$ meter square, while the lowest vegetables were planted in gardens with area 20-50 meter squares (Figure 4). Field crops planting was high practiced in gardens 20-50 meter square, while it was existed in most gardens with lower areas. The Aromatic and medical plants were increasing as the area of the household garden increases. The bearing trees are highly distributed in areas 20-50 meter square gardens. In other words, the most of type of crops are existed in gardens with areas $>200$ meter square, 100-200 square meters, 50-100 square meters. In areas of spaces less than 20 square meters lacks the lawns and forest trees (Figure 4).

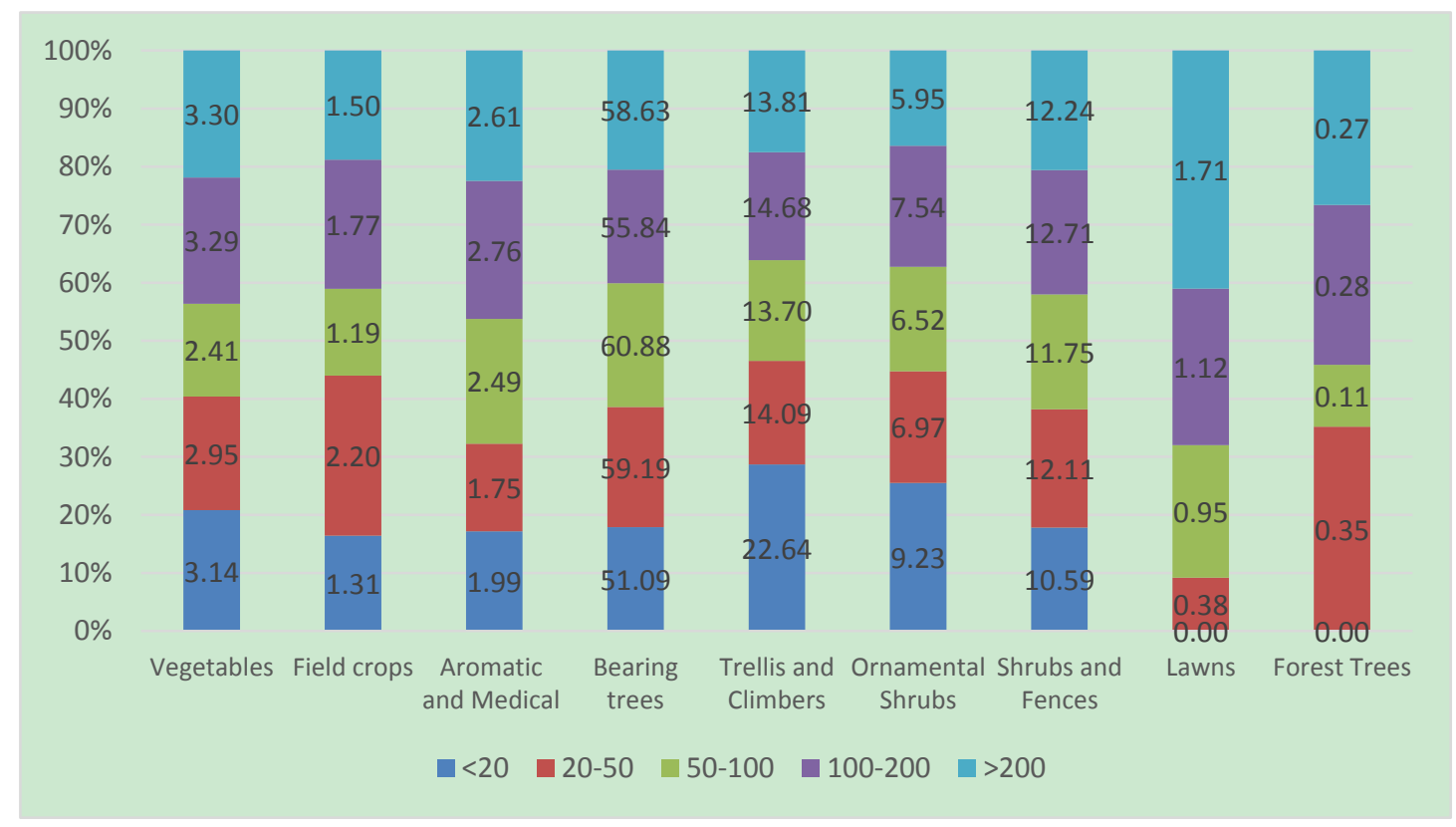

Figure 4 . The percentage of plant distribution according to the planting area

Figure 5 shows the status of household ownership and the existence of gardens. The results showed that the highest percentage of households with gardens are owned and they are planted by their owners.

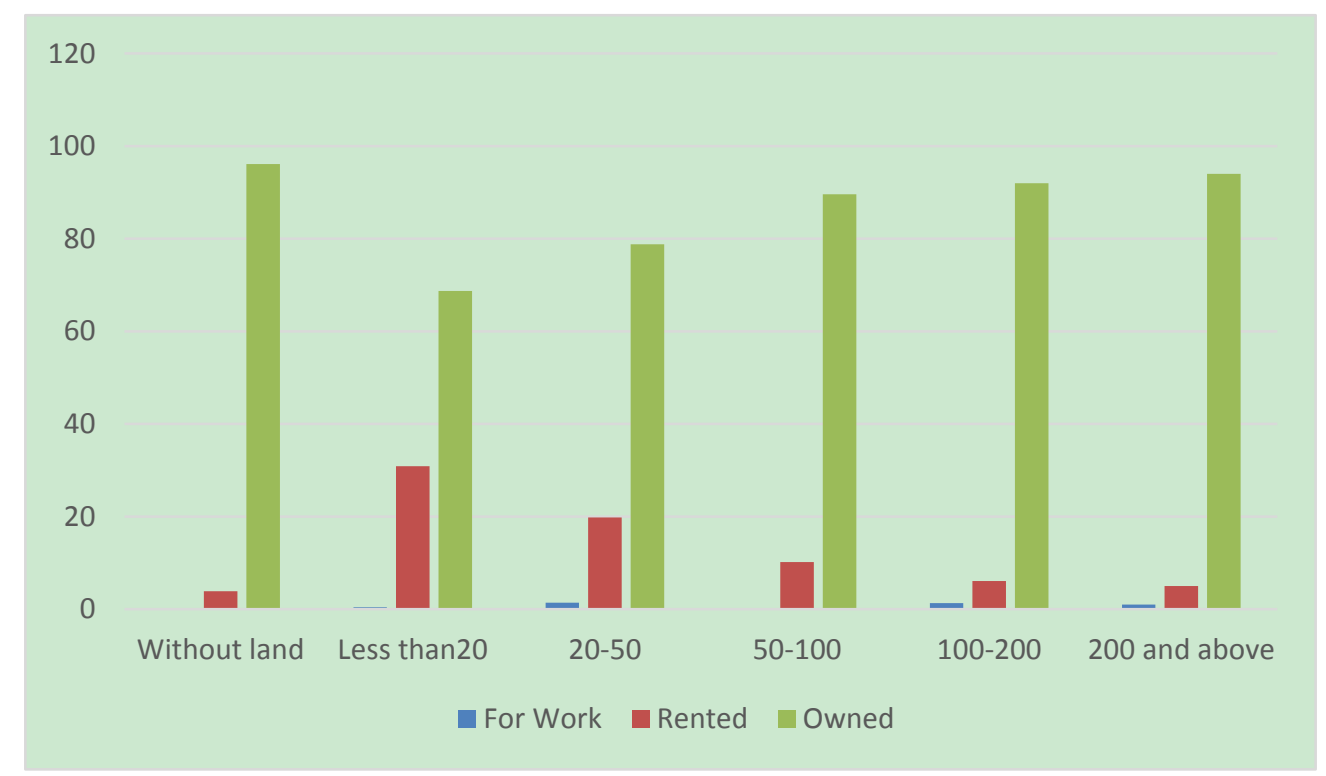

Figure 5. The distribution of gardens area according to the type of house possess 
Figure 6 shows the purpose of uses of household gardens. In the sixth layers of the study the results showed that, the production of the household gardens used for household consumption. The other use was concentrated as a household screen which provides privacy. The least use recorded was the production use for sale. On the other hand, many households showed that the care of gardens is for recreation and aeration purposes.

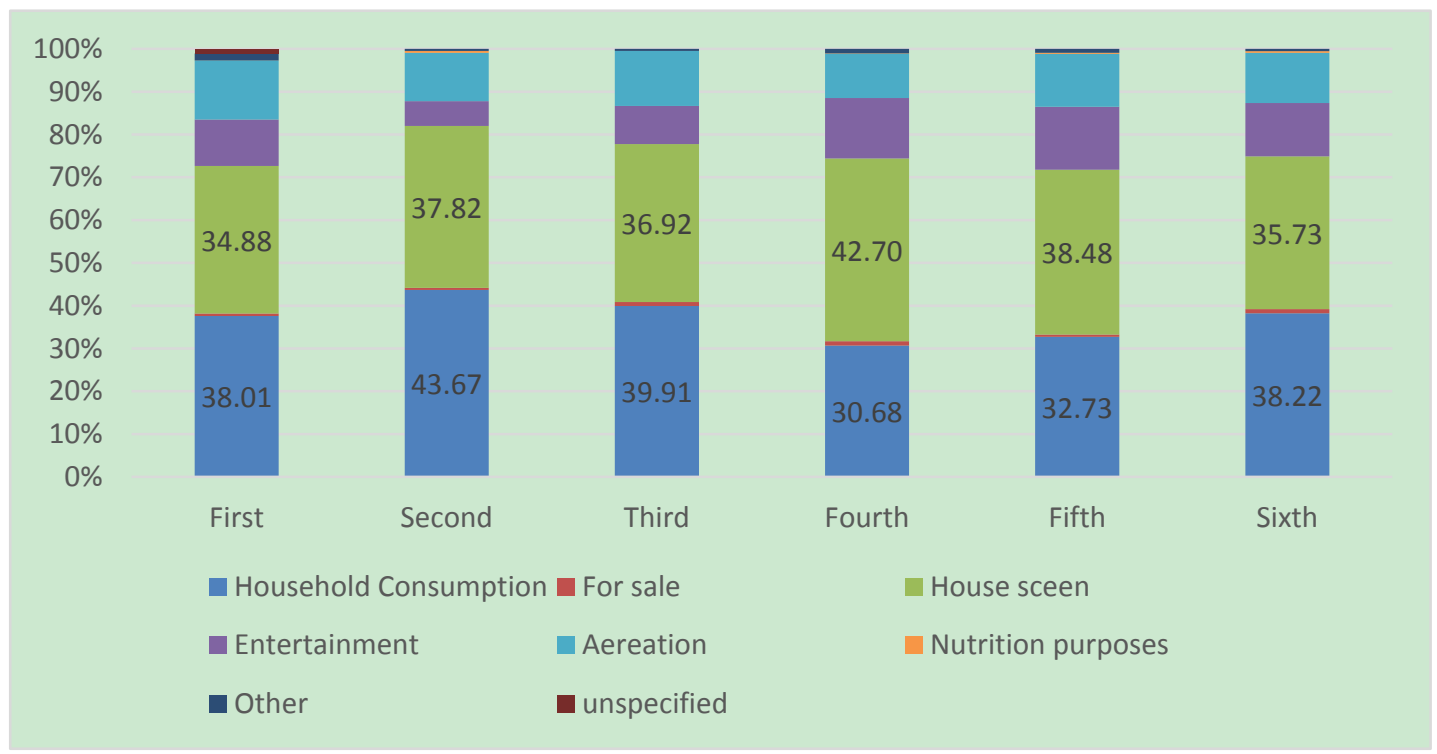

Figure 6. The distribution of gardens according to its purpose per layer

Despite the area of the household garden, the results showed that most families were care for the use of production for local consumption. The second purpose was to improve house scenery. The third importance was for entertainment and practice hobbies (Figure 7).

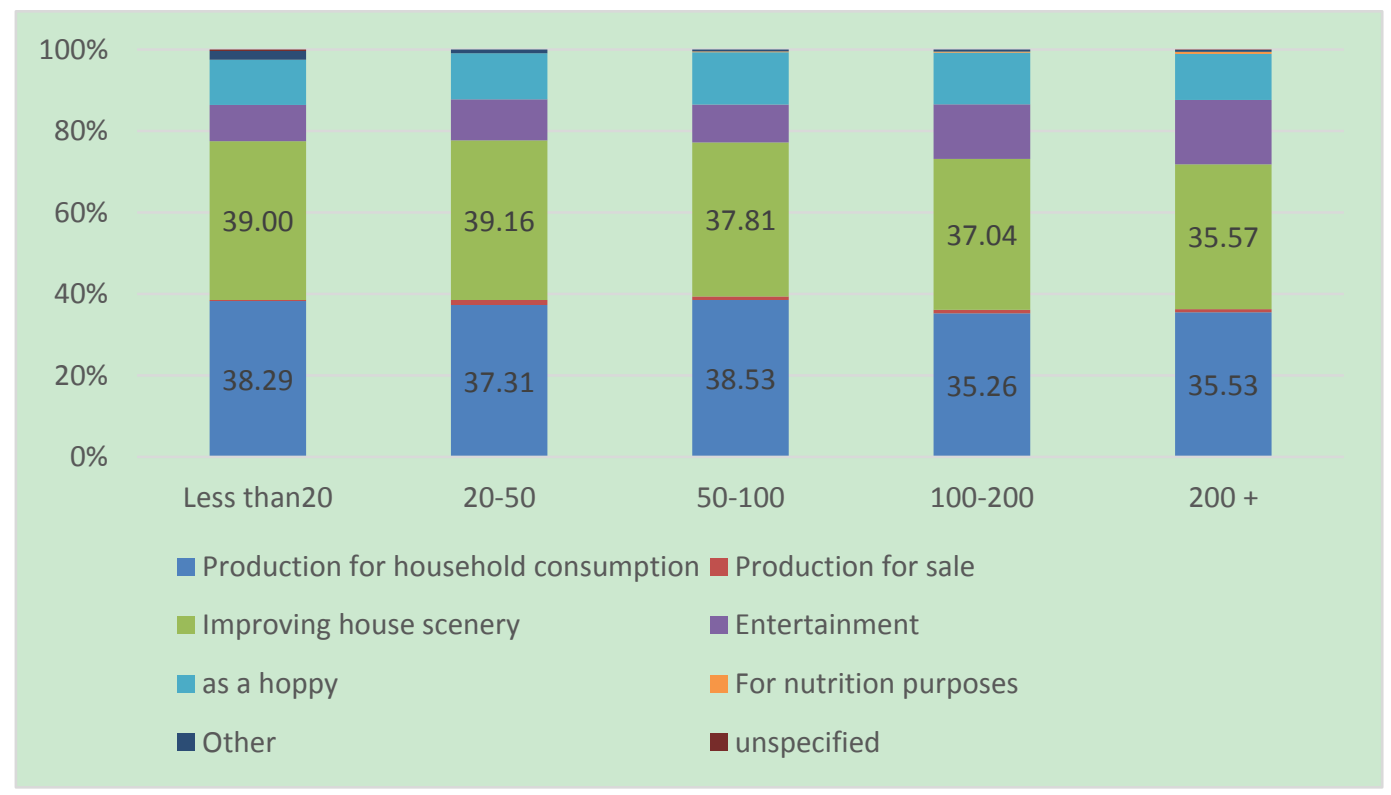

Figure 7. The purposes of household gardens according to its area

The results of figure 8 shows that the distribution of household gardens is not related to the family income. In first layer, the percentage of gardens is higher, while the income distribution is lower compared to the second layers. In third and fourth layers, the increase of income contributed to the increase of household gardens percentage compared to the first and the second layers. In fifth layer, the highest percentage of household gardens existed as the household income increased, while in sixth layer the highest percentage of household gardens as their households located suburb areas which facilitate practicing these activities. 

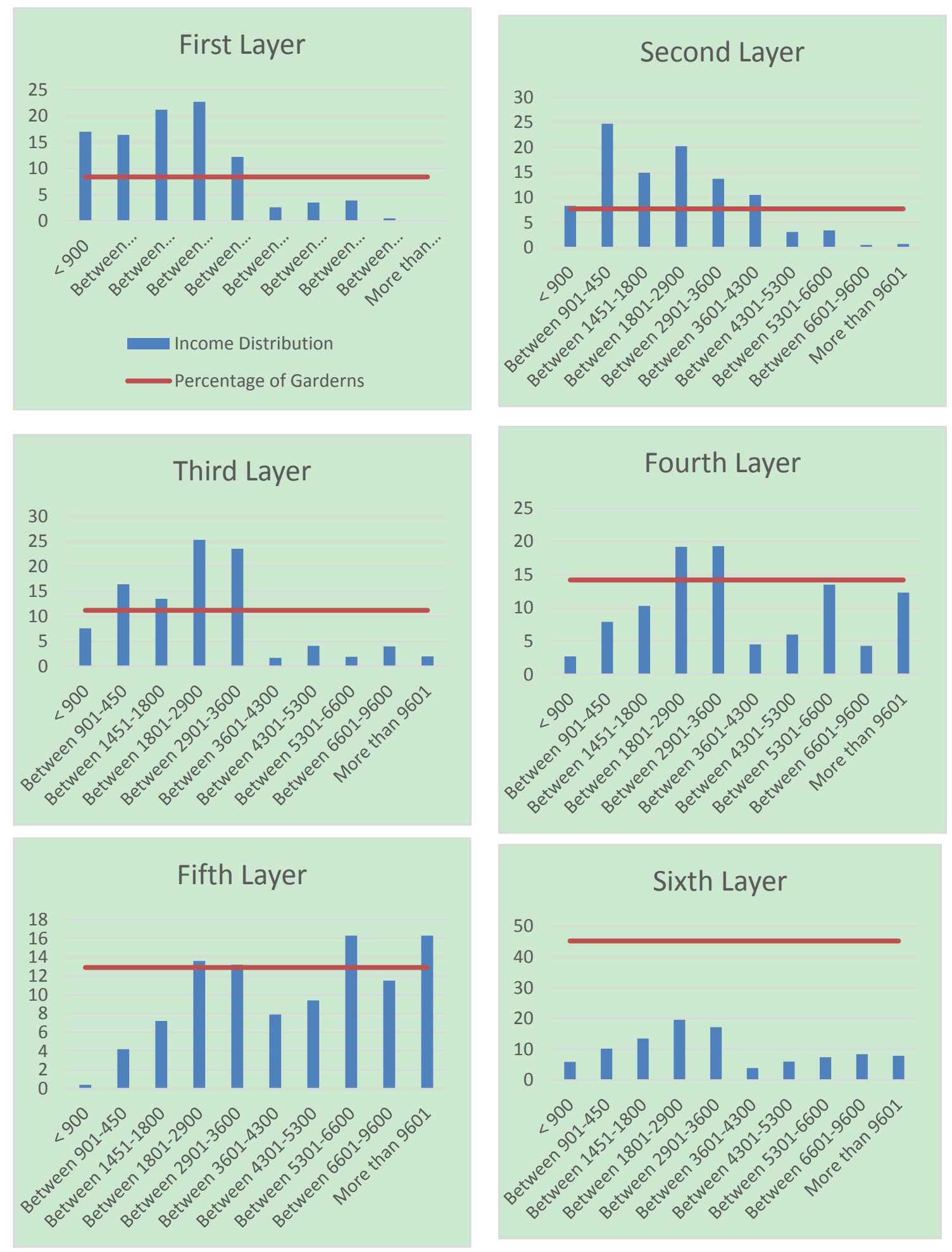

Figure 8. The effect of income on the distribution of household gardens

The results in Figure 9 shows that the lowest education level was more distributed and care for the household gardens. In the third and fourth layers the care for gardens was handled by the intermediate educational levels, while in the fifth layer it was handled by high educational level. In sixth layer, the care was distributed on low, intermediate and high educational levels (Figure 9). 

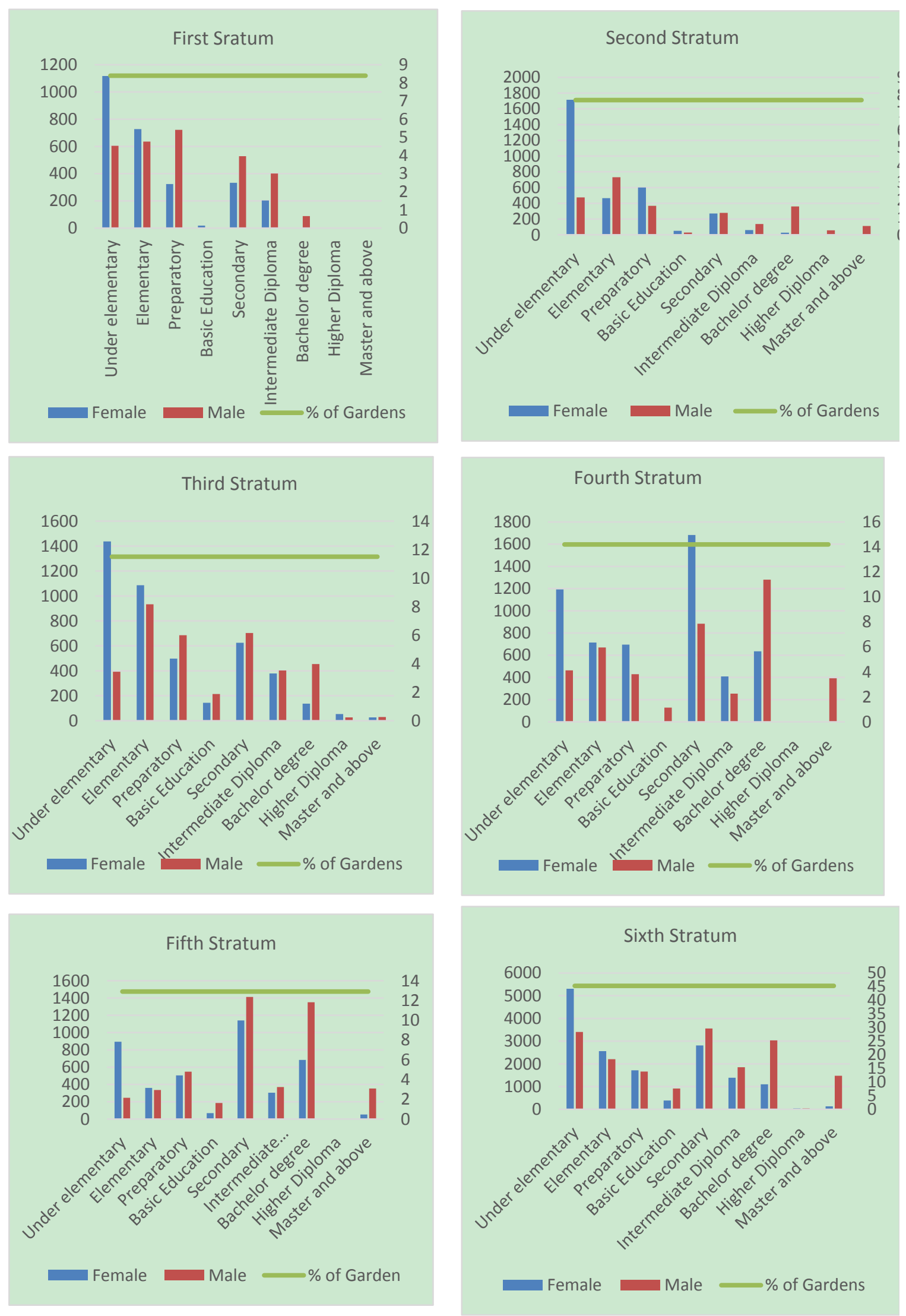

Figure 9. The effect of education level on the distribution of household gardens 


\section{Conclusions}

The objective of this paper is to highlight the socio-economical characteristics of households using the urban agriculture as part of their lives pattern. The questionnaire was a tool to collect data. The results showed that the distribution of household gardens was highly affected by the household income and the free space of household. The highest income was encouraging the families to have their home gardens. Also, the care for household gardens was affected by the educational levels of these families. In low income families, the care for gardens was taken over by low educational level individuals of the family, while in intermediate and high income the care for gardens was taken over by intermediate and high educational individuals in families. In the areas of suburbs, the situation was different due to the different social structure. The care for gardens was taken over by all educational levels. The use of production was for family consumption and the concentration was on creating some good entertainment environments inside household.

\section{References}

Abebe, T, Sterck, F, Wiersum, K, \& Bongers, F. (2013). Diversity, composition and density of trees and shrubs in agroforestry homegardens in Southern Ethiopia. Agrofor Syst., 87, 1283-1293. https://doi.org/10.1007/s10457-013-9637-6

Aguilar-Støen, M, Moe, SR, \& Camargo-Ricalde, SL. (2009). Home gardens sustain crop diversity and improve farm resilience in Candelaria Loxicha, Oaxaca, Mexico. Hum Ecol., 37, 55-77. https://doi.org/10.1007/s10745-008-9197-y

Avohou, HT, Vodouhe, RS, Dansi, A, Kpeki, B, \& Bellon, M. (2012). Ethnobotanical Factors Influencing the Use and Management of Wild Edible Plants of Agricultural Environments in Benin. Ethnobotany Research \& Applications, 10, 571-592.

Brun, T, Reynaud, J, \& Chevassus-Agnes, S. (1989). Food and nutritional impact of one home garden project in Senegal. Ecol Food Nutr., 23, 91-108. https://doi.org/10.1080/03670244.1989.9991092

Domene, E, \& Saurí, D. (2007). Urbanization and class-produced natures: Vegetable gardens in the Barcelona Metropolitan Region. Geoforum, 38, 287-298. https://doi.org/10.1016/j.geoforum.2006.03.004

Faber, M, Venter, SL, \& Benade, A. (2002). Increased vitamin A intake in children aged 2-5 years through targeted home-gardens in a rural South African community. Public Health Nutr., 5, 11-16. https://doi.org/10.1079/PHN2001239

Fandohan, B, Assogbadjo, AE, Glèlè Kakaï, RL, \& Sinsin B. (2011). Effectiveness of a protected areas network in the conservation of Tamarindus indica (Leguminosea-Caesalpinioideae) in Benin. Afr J Ecol., 49, 40-50. https://doi.org/10.1111/j.1365-2028.2010.01228.x

Igue, AM, Floquet, A, \& Stahr, K. (2000). Land use and farming systems in Benin. In F Graef, P Lawrence, and M von Oppen (editors) Adapted farming in West Africa: issues, potentials and perspectives, 227-238.

Mazumdar S, \& Mazumdar S. (2012). Immigrant home gardens: Places of religion, culture, ecology, and family. Landsc Urban Plan, 105, 258-265. https://doi.org/10.1016/j.landurbplan.2011.12.020

Rodrigue Castro Gbedomon, 囚 Adandé Belarmain Fandohan, Valère Kolawolé Salako, Alix Franck Rodrigue Idohou,Romain Glèlè Kakaï, \& Achille Ephrem Assogbadjo, (2015). Factors affecting home gardens ownership, diversity and structure: a case study from Benin. J. Ethnobiol Ethnomed, 11, 56. https://doi.org/10.1186/s13002-015-0041-3

Salako, VK, Fandohan, B, Kassa, B, Assogbadjo, AE, Idohou, AFR, Gbedomon, RC, Chakeredza, S, Dulloo, ME, \& Kakaï, RG. (2014). Home gardens: an assessment of their biodiversity and potential contribution to conservation of threatened species and crop wild relatives in Benin. Genet Resour Crop E., 61, 313-330. https://doi.org/10.1007/s10722-013-0035-8

Trinh, L, Watson, J, Hue, N, De, N, Minh, N, Chu, P, Sthapit, B, \& Eyzaguirre, P. (2003). Agrobiodiversity conservation and development in Vietnamese home gardens. Agr Ecosyst Environ., 97, 317-344. https://doi.org/10.1016/S0167-8809(02)00228-1

Watson, JW, \& Eyzaguirre, PB. (2002). Home gardens and in situ conservation of plant genetic resources in farming systems. Bioversity International. 